\title{
The Difference of Lipid Profile Pre and Post Endurance Exercise in Obese Male Adolescents
}

\author{
Agustina Mufidah $^{1}$, Sri Mardjiati Mei Wulan ${ }^{2}$, Dewi Poerwandari ${ }^{2 *}$, Hermina Novida $^{3}$, \\ Soenarnatalina Melaniani ${ }^{4}$ \\ *Email: nastitisoemarno@gmail.com \\ ${ }^{1}$ Resident, Department of Physical Medicine and Rehabilitation, Faculty of Medicine, Universitas Airlangga, \\ Dr. Soetomo Academic General Hospital, Surabaya, Indonesia \\ ${ }^{2}$ Lecturer/Doctor, Department of Physical Medicine and Rehabilitation, Faculty of Medicine, Universitas \\ Airlangga, Dr. Soetomo Academic General Hospital, Surabaya, Indonesia \\ ${ }^{3}$ Lecturer/Doctor, Department of Internal Medicine, Faculty of Medicine, Universitas Airlangga, Surabaya, \\ Indonesia \\ ${ }^{4}$ Lecturer, Department of Biostatistics and Demography, Faculty of Public Health, Universitas Airlangga, \\ Surabaya, Indonesia
}

\begin{abstract}
Obesity among adolescents has short-term and long-term consequences in terms of physical and psychosocial development. In adolescence obesity often causes serious complications such as hypertension, dyslipidemia, insulin resistance, dysglycemia, fatty liver, psychosocial complications. Dyslipidemia in obesity is closely related to the occurrence of atherosclerosis which often leads to coronary heart disease (CHD) and vascular disorders. Dyslipidemia is indicated by an increase in total cholesterol, low density lipoprotein (LDL), or triglycerides (TG), or a decrease in high density lipoprotein (HDL). Boys have a higher visceral fat ratio than girls. Physical exercise without dietary restrictions has been shown to improve blood lipid profiles and reduce fat mass. Endurance exercise increases fat oxidation during submaximal exercise. Zumba has been shown to reduce fat mass and improve aerobic fitness. To analyze the effect of endurance exercise with Zumba fitness $3 \mathrm{x} /$ week for 8 weeks on the lipid profile of obese male adolescents at senior high school Surabaya. This study was conducted from July 2020 to August 2020. The research subjects were 12 teenage boys aged 14-18 years at senior high school Surabaya, with obesity nutritional status $p>95$ according to CDC 2000. Research subjects were given an endurance exercise intervention with Zumba fitness 3 times a week for 8 weeks, light-moderate intensity 30-60 minutes. The volume of exercise is gradually increased by starting with an increase in duration and then the intensity of the exercise includes whole body movement with a combination of aerobics and dance. This study was conducted without calorie restriction. Pre- and post-exercise assessment of lipid profile (total cholesterol, triglycerides, HDL and LDL). TG, HDL, and total cholesterol before and after exercise had no significant difference which is TG $=0.106, \mathrm{HDL}=0.259$ and total cholesterol $=0.188$. Pre- and post-exercise LDL data had a significant difference with a significance value of 0.014 for LDL. In this study, there was a $6.8 \%$ decrease in TG; decreased LDL $4.9 \%$; increase in HDL 12.49\%; and a 3.6\% reduction in total cholesterol. Endurance exercise with zumba fitness 3 times in a week for 8 weeks in obese male adolescents without calorie restriction, can improve LDL lipid profile, but does not improve TG, HDL and total cholesterol.
\end{abstract}

Keywords: Endurance exercise, Zumba fitness, lipid profile, adolescents, obesity

\section{INTRODUCTION}

Obesity in children and adolescents is a health epidemic throughout the world, both advanced and developing countries (Elissa and Whitney, 2016). The prevalence of overweight and obesity in children in the world increased from $4.2 \%$ in 1990 to $6.7 \%$ in 2010, and is expected to reach $9.1 \%$ in 2020 . More than $10 \%$ of children in big cities in Indonesia have experienced obesity. Based on data from the 2013 Basic Health Research (Riskesdas) the prevalence of obesity in children aged 5-12, 13-15, and 16-18 years old based on body mass index, respectively, $8.8 \%, 2.5 \%$, and $1.6 \%$ (Madarina, 2014; Damayanti et al, 2014).

Obesity among adolescents has short-term and long-term consequences in terms of physical and psychosocial development (Elissa and Whitney, 2016). In adolescence obesity often causes serious complications such as hypertension, dyslipidemia, insulin resistance, dysglycemia, fatty liver, psychosocial complications, and can also be a major contributor to health care costs (Neslihan, 2014). Dyslipidemia in obesity is closely related to the occurrence of atherosclerosis which often leads to heart attacks or coronary heart disease (CHD) and vascular disorders. Dyslipidemia is indicated by an increase in total cholesterol, LDL, or triglycerides, or a decrease in HDL. The most dangerous subtype of LDL is small dense LDL (Kaniawati et al, 2019; Blanca et al, 2013). Riskesdas 2013 stated that the Indonesian population aged 15 years had total cholesterol levels exceeding the normal value of $35.9 \%$, HDL-C levels below normal $22.9 \%$ and LDL-C levels above normal values with near 
optimal and borderline 60 categories. 3\%, high and very high categories $15.9 \%$, and high and very high triglyceride levels $11.9 \%$ (Kaniawati et al, 2019).

The pattern of body fat between men and women is different, this is influenced by hormones and will be very influential at puberty. In men affected by android hormones, relatively large fat accumulates in the upper body, while in women affected by gynoid hormones, body fat is relatively large in the hip and thigh (Helen, 2008). Men have a greater amount of visceral fat than women. Boys have higher visceral fat than subcutaneous fat than girls. This indicates that proportionally more adipose tissue is stored intra-abdominally (Suliga, 2009). The effect of obesity on lipid metabolism depends on the location of the adipocyte tissue. Increases in visceral adipose tissue and subcutaneous adipose tissue (especially the upper limb) are associated with higher triglycerides and lower HDL cholesterol levels. Increased subcutaneous adipose tissue in the limbs is associated with lower triglycerides, which explains why African-American women have lower triglycerides. An increase in visceral adipose tissue and subcutaneous adipose tissue of the upper ribs is associated with insulin resistance, which can contribute to lipid changes (Kenneth and Carl, 2018).

The large number of complications in obese adolescents makes it important to prevent childhood obesity and identify overweight and obese children at an early stage, so that they can start treatment to achieve or maintain a healthy weight (Neslihan, 2014). Evaluation of overweight and obese adolescents should include a fasting lipid profile and family history for risk factors and cardiovascular disease. Recent studies have shown dramatic changes in the health status of children and adolescents due to poor nutrition and lifestyle. Being overweight is associated with adolescent inactivity, so a healthy lifestyle and weight management counseling is essential. Exercise and activity interventions associated with decreased visceral adipocytes and increased muscle mass can correct lipid abnormalities before significant weight loss is achieved (Brian, 2010; Mehdi et al, 2014).

Weight loss achieved by diet or exercise has been shown to reduce triglyceride (TG) levels and increase High Density lipoprotein (HDL) cholesterol levels. Many studies conclude that fat reduction through diet or exercise results in beneficial plasma lipoprotein changes (Blanca et al, 2013; Kaniawati et al, 2019). Physical exercise without dietary restrictions has been shown to improve blood lipid profiles and reduce fat mass. It is not known which mode of exercise is most efficient for enhancing responsiveness to lipid profiles. Endurance exercise can improve lipid profiles without dietary restrictions, but McGuigan et al (2009) said that aerobic exercise in children and adolescents is less tolerable because excess body weight causes an increase in the intensity of weightbearing activities so that it is easier to drop out (Aucouturier and Thivel, 2003). 2015; Blanca et al, 2013).

In addition, there is zumba which is a mix of popular music with dance that is entertaining and can improve the health of all age groups. The physiological effects of zumba can be used as an adjunct to conventional therapy for the prevention of various lifestyle diseases such as diabetes and obesity. Zumba is considered better than running and spinning. Zumba has been shown to reduce fat mass and improve aerobic fitness (Manjula et al, 2018). There are currently few studies that describe the relationship between endurance training and zumba fitness on lipid profiles in obese male adolescents. Therefore, this present study aims to determine the differences in lipid profiles before and after endurance exercise with the zumba fitness method in obese male adolescents. Zumba fitness accompanied by the teenagers' favorite music is expected to increase exercise compliance among teenagers, so that it will increase the activity of obese teenagers to improve their health status.

\section{METHODS}

\section{Research Design}

This study aimed to compare the effects of pre and post endurance exercise with Zumba fitness without calorie restriction on the lipid profile of obese adolescent boys. The research method used is experimental in a group of adolescents with obesity aged 14-18 years. The treatment given to the group was endurance training with zumba fitness. The form of the research design can be described as follows:

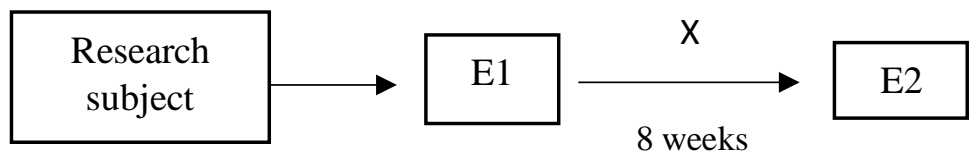

Figure 1. Research design

Descriptions:

$\mathrm{X}$ : Endurance exercise with Zumba Fitness

E1 : Endurance exercise group (before intervention)

E2 : Endurance exercise group (after intervention) 


\section{Research Design}

1. The research population is adolescents (aged 14-18 years) with obesity in senior high school Surabaya.

2. The subjects of the study were adolescents (aged 14-18 years) with obesity who were students of senior high school Surabaya who met the inclusion criteria and did not include the exclusion criteria, until the number of samples was met.

3. The sample size in the study was determined based on the Lwanga \& Lemeshow (2003) formula, namely:

$$
\begin{array}{ll}
\mathrm{n} & =\frac{(\mathrm{Z} 1 / 2 \alpha+\mathrm{Z} \beta)^{2} \cdot \sigma^{2}=10}{\left(\mu_{1}-\mu_{2}\right)^{2}} \\
\mathrm{n} & =\text { number of subjects in the group. } \\
\mathrm{Z} 1 / 2 \alpha & =\text { raw Deviat alpha }(\alpha=0.05)=1.96 \\
\mathrm{Z} \beta & =\text { raw Deviat beta }(\beta=0.20)=0.842 \\
\mu 1=1.09 & \mu 2=1,03 \text { (Ben ounis et al, 2008) }
\end{array}
$$

Anticipation of dropping out of the $20 \%$ test is $2, n=10+2=12$ people. So, the number of research subjects is $12 \mathrm{men}$.

4. The technique of taking research subjects using consecutive sampling techniques.

\section{Research Subject Criteria}

1. Inclusion criteria

a. Male aged 14-18 years.

b. Body mass index according to age percentile (CDC BMI chart 2000) $>\mathrm{P}_{95}$

c. Subjects are willing to participate in this study by signing an informed consent form and the subject's parents agreed to the subject's involvement by signing the consent form as a witness.

2. Exclusion criteria

a. Undergoing a regular structured exercise program (at least 2 times a week) in the last 2 months.

b. Have a history of ischemic heart disease, heart failure.

c. Have a history of asthma triggered by physical activity

d. Having comorbidities that require the subject to take medication regularly and affect body composition such as Cushing's syndrome, DM, hypothyroidism.

e. Have a neuromusculoskeletal disease.

f. Impaired vision and hearing so that it can interfere with audiovisual communication

3. Dropout criteria

a. Research subjects are not willing to continue the research for any reason.

b. Subjects could not complete the exercise in accordance with the established research protocol, namely not following the program for 3 consecutive training sessions from the number of training sessions for 8 weeks.

c. Subjects experienced complications during the exercise program such as shortness of breath, syncope, chest pain and other complications that made it impossible to continue the exercise.

\section{Research variables}

1. Independent variable

- Endurance training with Zumba fitness

2. Dependent variable

- Lipid profile (Total cholesterol, Triglycerides, HDL, and LDL)

3. Confounding variables

- Daily food intake.

- Daily physical activity.

\section{Research Instruments}

The instruments used in this research are:

a. Borg scale

b. Riester brand sphygmomanometer

c. Littmann stethoscope

d. Elitech ${ }^{\circledR}$ fox-2 brand Pulse oximeter

e. Stopwatch

f. Informed Assent sheet and data collection sheet

g. Caliper 
h. Blood set

i. Emergency kit, which consists of:

- One unit of oxygen cylinder, mask and oxygen hose

- Ambu bag

- Epinephrine injection $2 \mathrm{ml}$

- $3 \mathrm{ml}$ injection syringe $23 \mathrm{G}$

- Injection syringe $1 \mathrm{ml}$ size $23 \mathrm{G}$

- Povidone Iodine

- $\quad$ Sterile gauze and plaster

\section{Data Analysis}

Data were analyzed computerized with SPSS v20.o using the following tests:

- Saphiro Wilks test for normality test.

- $\quad$ Paired t-test to compare the lipid profile pre and post endurance exercise with zumba fitness for 8 weeks, if normally distributed.

- Mann Whitney test to compare lipid profile pre and post endurance exercise with zumba fitness for 8 weeks, if the distribution is not normal.

\section{RESULTS AND DISCUSSIONS}

This research received ethical approval from the Health Research Ethics Committee, Faculty of Medicine, Universitas Airlangga, Surabaya with No. 121/EC/KEPK/FKUA/2020. This research was conducted at senior high school Surabaya. There was one group of research subjects who received an endurance exercise intervention. Endurance exercise begins with light intensity (THR: 57-64\% HRMax) gradually increased to moderate intensity (THR: 64-76\% HRMax) with aerobic exercise (zumba fitness) for 30-60 minutes, gradually increasing (preceded by a 5-10-minute warm-up), core 20-40 minutes, cooling down 5-10 minutes), frequency 3 times a week for 8 weeks. The calculation of HRMax using the Astrand formula is HRMax $=216.6-(0.84 \mathrm{x}$ Age) (Castellani et al, 2014). Exercise includes whole body movement with a combination of aerobics and dance. The volume of exercise is increased gradually, starting with increasing duration and then increasing in intensity.

The parameters evaluated in this study were body mass index (BMI), subcutaneous fat (arm, waist, and hip), abdominal circumference, and lipid profile values (total cholesterol, triglycerides, high density lipoprotein (HDL), and low-density lipoprotein (LDL)). This assessment was carried out twice, namely pre and post research. The total subjects of this study were 13 obese male adolescents. There is 1 subject who dropped out of the test because the training schedule clashed with school activities.

\section{Characteristics of Research Subjects}

The number of subjects analyzed in this study were 12 male adolescents who were diagnosed with obesity according to the 2000 CDC scheme. The data normality test used the Saphiro Wilk test, the distribution of the initial data showed a normal distribution on the variables BMI, subcutaneous fat (arm, waist and hip skinfold), abdominal circumference and lipid profile (total cholesterol, triglycerides, and low-density lipoprotein). Age and HDL variables were not normally distributed.

The results of the Saphiro Wilk test (Table 1) showed that the data of BMI, subcutaneous fat, abdominal circumference, lipid profile (total cholesterol, triglycerides, and low-density lipoprotein) pre- and post-exercise were normally distributed so that the parametric statistical test was used with paired t-test. HDL data is not normally distributed, so Mann Whitney test is used as a non-parametric test.

Table 1. Pre and Post Normality Test

\begin{tabular}{|llllc|}
\multicolumn{3}{l}{ Variables } & $\begin{array}{l}\text { Pre-Exercise } \\
\text { Mean p-value }\end{array}$ & \multicolumn{3}{c|}{$\begin{array}{l}\text { Post-Exercise } \\
\text { Mean p-value }\end{array}$} \\
\hline BMI $\left(\mathrm{kg} / \mathrm{m}^{2}\right)$ & $32.77 \pm 3.77$ & $0.839^{*}$ & $29.52 \pm 3.87$ & $0.943^{*}$ \\
Age (years) & $15.50 \pm 0.52$ & 0.000 & - & - \\
Arm skinfold (mm) & $32.33 \pm 2.96$ & $0.147^{*}$ & $22.58 \pm 5.10$ & $0.665^{*}$ \\
Waist skinfold (mm) & $36.42 \pm 3.42$ & $0.075^{*}$ & $27.08 \pm 5.16$ & $0.092^{*}$ \\
Hip skinfold (mm) & $33.83 \pm 4.04$ & $0.683^{*}$ & $25.17 \pm 3.99$ & $0.438^{*}$ \\
Abdominal circumference (cm) & $105.79 \pm 7.38$ & $0.121^{*}$ & $101.79 \pm 8.29$ & 0.169 \\
TG (mg/dl) & $98.67 \pm 46.08$ & $0.162^{*}$ & $91.92 \pm 40.29$ & $0.232^{*}$ \\
LDL (mg/dl) & $108.83 \pm 29.21$ & $0.064^{*}$ & $103.42 \pm 25.53$ & $0.155^{*}$ \\
HDL (mg/dl ) & $53.75 \pm 17.74$ & 0.007 & $60.67 \pm 21.50$ & 0.011 \\
\hline
\end{tabular}


Total cholesterol $(\mathrm{mg} / \mathrm{dl})$

$172.33 \pm 30.33 \quad 0.410^{*}$

$166.00 \pm 28.49$

$0.991^{*}$

*Shapiro Wilk test is normally distributed when p-value $>0.05$

The results of the Saphiro Wilk test (Table 1) show that the pre- and post-exercise body mass index (BMI) data are normally distributed. The average pre-exercise body mass index was $32.77 \pm 3.77 \mathrm{~kg} / \mathrm{m} 2$ with a p-value of 0.839 , and an average post-exercise $29.52 \pm 3.86 \mathrm{~kg} / \mathrm{m} 2$ with a p-value of 0.943 . Effect size $t$ test (Cohen's d) for BMI 1.37 (very large). Age data showed no normal distribution, the mean age was $15.50 \pm 0.52$ years with a pvalue of 0.000 .

The results of the Saphiro Wilk test (Table 1) show that the Arm skinfold data pre and post-exercise are normally distributed. The pre-exercise arm skinfold averaged $32.33 \pm 2.96 \mathrm{~mm}$ with a p-value of 0.147 . Postexercise arm skinfold averaged $22.58 \pm 5.10 \mathrm{~mm}$ with a p-value of 0.665 . Effect size $\mathrm{t}$ test (Cohen's d) for arm skinfold 2.28 (very large).

The results of the Saphiro Wilk test (Table 1) showed that the pre- and post-exercise waist skinfold data were normally distributed. The pre-exercise waist skinfold averaged $36.42 \pm 3.42 \mathrm{~mm}$ with a p-value of 0.075 . Waist skinfold after exercise was $27.08 \pm 5.16 \mathrm{~mm}$ with a p-value of 0.438 . Effect size $t$ test (Cohen's d) for waist skinfold 1.68 (very large).

The results of the Saphiro Wilk test (Table 1) showed that the pre- and post-exercise hip skinfold data were normally distributed. The pre-exercise hip skinfold averaged $33.83 \pm 4.04 \mathrm{~mm}$ with a p-value of 0.683 . The postexercise hip skinfold averaged $25.17 \pm 3.99 \mathrm{~mm}$ with a $\mathrm{p}$-value of 0.438 . Effect size $\mathrm{t}$ test (Cohen's d) for hip skinfold 1.73 (very large).

The results of the Saphiro Wilk test (Table 1) showed that the pre- and post-exercise abdominal circumference data were normally distributed. The mean pre-exercise abdominal circumference was $105.79 \pm$ $7.38 \mathrm{~cm}$ with a p-value of 0.121 . The average post-exercise abdominal circumference was $101.79 \pm 8.29 \mathrm{~cm}$ with a p-value of 0.169. Effect size $t$ test (Cohen's d) for abdominal circumference 1.03 (very large).

The results of the Saphiro Wilk test (Table 1) showed that the pre- and post-exercise Triglyceride (TG) data were normally distributed. Pre-exercise triglycerides averaged $98.67 \pm 46.08 \mathrm{mg} / \mathrm{dl}$ with a p-value of 0.162 . Postexercise triglycerides averaged $91.92 \pm 40.29 \mathrm{mg} / \mathrm{dl}$ with a p-value of 0.232 .

The results of the Saphiro Wilk test (Table 1) show that the data of low-density lipoprotein (LDL) pre- and post-exercise are normally distributed. The average pre-exercise LDL was $108.83 \pm 29.21 \mathrm{mg} / \mathrm{dl}$ with a p-value of 0.064 . The average post-exercise LDL was $103.42 \pm 25.53 \mathrm{mg} / \mathrm{dl}$ with a p-value of 0.155 .

The results of the Saphiro Wilk test (Table 1) showed that the pre-exercise High Density Lipoprotein (HDL) data was not normally distributed. The mean pre-exercise HDL was $53.75 \pm 17.74 \mathrm{mg} / \mathrm{dl}$ with a p-value of 0.007 . The mean post-exercise HDL was $60.67 \pm 21.50 \mathrm{mg} / \mathrm{dl}$ with a p-value of 0.011 .

The results of the Saphiro Wilk test (Table 1) showed that the total cholesterol data before and after exercise were normally distributed. Pre-exercise total cholesterol averaged $172.33 \pm 30.33 \mathrm{mg} / \mathrm{dl}$ with a p-value of 0.410 . The average post-exercise total cholesterol was $166.00 \pm 28.49 \mathrm{mg} / \mathrm{dl}$ with a p-value of 0.991 .

Data on BMI, subcutaneous fat (arm, abdomen and hip skinfold), and abdominal circumference used parametric statistical tests because the data were normally distributed as shown in Table 2 . The parametric test uses paired t-test. Data were taken before and after endurance exercise with Zumba fitness

Table 2. Data on BMI, Subcutaneous Fat and Abdominal Circumference Pre and Post Endurance Exercise

\begin{tabular}{|llll|}
\hline variables & $\begin{array}{c}\text { Pre-exercise } \\
(\mathbf{n}=\mathbf{1 2})\end{array}$ & $\begin{array}{c}\text { Post-exercise } \\
(\mathbf{n}=12)\end{array}$ & significance * \\
\hline BMI $(\mathrm{kg} / \mathrm{m} 2)$ & $32.77 \pm 3.77$ & $29.52 \pm 3.87$ & 0.001 \\
Arm Skinfold $(\mathrm{mm})$ & $32.33 \pm 2.96$ & $22.58 \pm 5.10$ & 0.000 \\
Waist skinfold $(\mathrm{mm})$ & $36.42 \pm 3.42$ & $27.08 \pm 5.16$ & 0.000 \\
Hip skinfold $(\mathrm{mm})$ & $33,83 \pm 4.04$ & $25.17 \pm 3.99$ & 0.000 \\
Abdominal circumference $(\mathrm{cm})$ & $105.79 \pm 7.38$ & $101.79 \pm 8.29$ & $0.004^{*}$ \\
\hline
\end{tabular}

*paired $t$ test, the difference is significant if the value significance $<0.05$

The results of the paired t-test (Table 2) showed that the data on BMI, subcutaneous fat (arm, abdomen and hip skinfold), and pre- and post-exercise abdominal circumference had significant differences. There was a decrease in BMI, subcutaneous fat and abdominal circumference with a significance value $<0.05$

\section{Triglyceride Data Pre and Post Endurance exercise with Zumba fitness.}


Triglyceride data analysis was performed using parametric statistical tests because the data were normally distributed. The parametric test uses paired t-tests. Data is taken before and after endurance training with Zumba fitness.

Table 3. Triglyceride Data Pre and Post Endurance Exercise

\begin{tabular}{|llll|}
\hline variable & Pre-exercise $(\mathbf{n}=\mathbf{1 2})$ & Post-exercise $(\mathbf{n}=\mathbf{1 2})$ & significance* \\
\hline TG $(\mathrm{mg} / \mathrm{dl})$ & $98.67 \pm 46.08$ & $91.92 \pm 40.29$ & 0.106 \\
\hline
\end{tabular}

*test paired t-test, the difference is significant if the value is significance $<0.05$.

The results of the paired t-test (Table 3) show that the pre- and post-exercise TG data have an insignificant difference, with a significance value $>0.05$. Decrease in TG 6.8\% with effect size t test (Cohen's d) 0.51 (enough)

3. Data of LDL (Low Density Lipoprotein) Pre and Post Endurance Exercise with Zumba Fitness.

Data of LDL used parametric statistical tests because the data is normally distributed. The parametric test uses paired t-tests. Data were taken before and after endurance exercise with Zumba fitness.

Tabel 4 Data of LDL Pre dan Post Endurance Exercise

\begin{tabular}{|llll|}
\hline variable & Pre-exercise $(\mathbf{n}=\mathbf{1 2})$ & Post-exercise $(\mathbf{n}=\mathbf{1 2})$ & significance* \\
\hline $\mathrm{LDL}(\mathrm{mg} / \mathrm{dl})$ & $108.83 \pm 29.21$ & $103.42 \pm 25.53$ & $0.014^{*}$ \\
\hline
\end{tabular}

*paired t-test, significant difference if the value of significance $<0.05$

The results of the paired t test (Table 4) show that the data of LDL before and after exercise have a significant difference with a significance value of $<0.05$. LDL reduction $4.9 \%$ with effect size t-test (Cohen's d) 0.83 (large).

4. Data of HDL (High Density Lipoprotein) Pre and Post Endurance Exercise with Zumba fitness.

Data of HDL used non-parametric tests because it is not normally distributed. Non-parametric test used Mann Whitney test. Data were taken before and after endurance training with Zumba fitness.

Table 5 Data of HDL pre and post Endurance exercise

\begin{tabular}{|llll|}
\hline variable & Pre-exercise $(\mathbf{n}=\mathbf{1 2})$ & Post-exercise $(\mathbf{n}=\mathbf{1 2})$ & significance* \\
\hline HDL $(\mathrm{mg} / \mathrm{dl})$ & $53.75 \pm 17.74$ & $60.67 \pm 21.50$ & 0.259 \\
\hline
\end{tabular}

*paired t-test, the difference is significant if the value is significant $<0.05$

Based on the Mann Whitney test for HDL data, there is no significant difference with a significance value of $>0.05$. An increase in HDL of $12.49 \%$ with an effect size of 0.01 (small).

5. Data on Total Cholesterol Pre and Post Endurance Exercise with Zumba Fitness.

Total cholesterol data used a parametric statistical test because the data is normally distributed. The parametric test uses paired t-tests. Data were taken before and after endurance exercise with Zumba fitness.

Table 6. Total Cholesterol Data Pre and Post Endurance Exercise

\begin{tabular}{|llll|}
\hline Variable & Pre-exercise $(\mathbf{n}=12)$ & Post-exercise $(\mathbf{n}=12)$ & Significance* \\
\hline Total cholesterol $(\mathrm{mg} / \mathrm{dl})$ & $172.33 \pm 30.33$ & $166.00 \pm 28.49$ & 0.188 \\
\hline
\end{tabular}

*paired t-test, the difference is significant if value significance $<0.05$

The results of the paired t-test (Table 6) show that the pre- and post-exercise total cholesterol data have no significant difference, with a significance value $>0.05$. Decrease in total cholesterol $3.6 \%$ with effect size t-test (Cohen's d) 0.40 (small). 


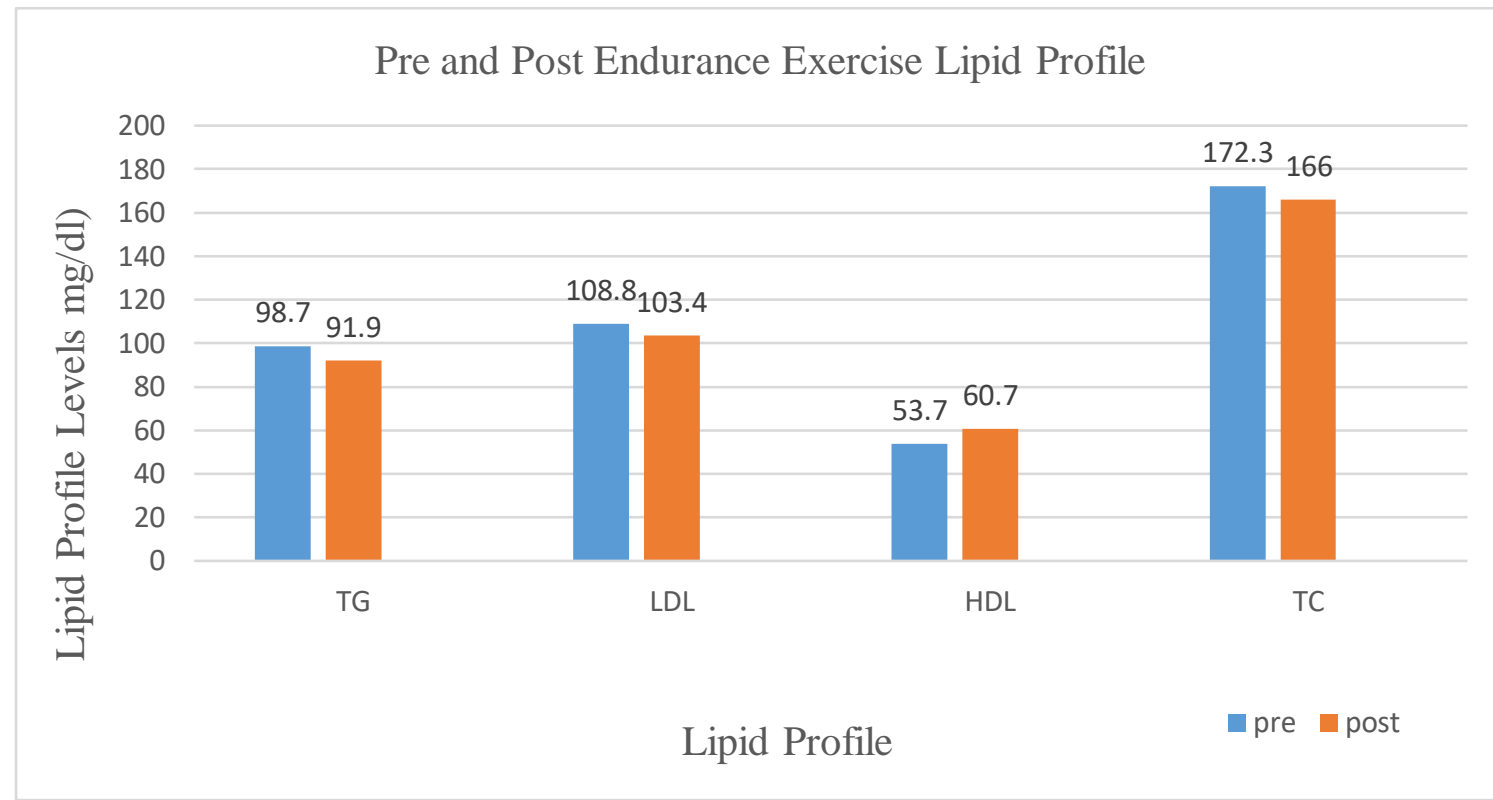

Figure 2. Graph of differences in lipid profiles pre and post 8 weeks of endurance exercise. TG = triglycerides; LDL $=$ Low Density Lipoprotein; HDL = High Density Lipoprotein; $\mathrm{TC}=$ Total cholesterol .

\section{Characteristics of Research Subjects}

This research was conducted at senior high school Surabaya during July 2020-September 2020. The subjects who met the inclusion criteria were 13 people, one study subject dropped out due to the training schedule in conjunction with school activities. The subjects of this study received an endurance training intervention that started with light intensity (THR: 57-64\% HR max) gradually increased to moderate intensity (THR: 64-76\% HR max) with aerobic exercise (Zumba fitness) for 60 minutes (10 warm-up) minutes, core 40 minutes, cool down 10 minutes), frequency 3 times for 8 weeks, music rhythm for zumba adjusted to the intensity (130-170 bpm for moderate intensity). During exercise no side effects were reported.

Initial characteristics of research subjects based on BMI, subcutaneous fat (arm, waist and hip), abdominal circumference and lipid profile (triglycerides, low density lipoprotein, and total cholesterol) were normally distributed for pre and post-study data. The variables of age and HDL were not normally distributed. There are $50 \%$ of research subjects who have an abnormal lipid profile, this proves that obese adolescents are prone to dyslipidemia. Dyslipidemia, which is not diagnosed and treated immediately, will certainly cause complications in obese adolescents.

\section{Analysis of Triglyceride Pre and Post Endurance Exercise}

This study explains that there is no significant difference for TG. There was a $6.8 \%$ decrease in TG, and the effect size was sufficient for TG. In this study, there was no calorie restriction, there was no monitoring of the type of diet consumed. This is thought to be a contributing factor to the insignificant difference for TG. Based on research by Gadha (2009), 75\% cholesterol is formed in the liver, while $25 \%$ is obtained from food intake. Gadha stated that the increase in cholesterol levels above the normal value was caused by excessive intake of foods derived from animal fats, eggs and foods that are currently referred to as junk food. Triglyceride levels in the blood are much influenced by the carbohydrate content of food and obesity. The study of Figueredo et al (2017), a diet with high levels of saturated fatty acids (SFA), especially high fat (high fat (HF)) will affect the inflammatory process.

The findings from a recent meta-analysis of Escalante et al (2012), discussing aerobic exercise and lipid profiles in children and adolescents conducted in the United States stated that short-term endurance exercise did not improve HDL-C, LDL-C, or TC lipid profiles, but reduces TG. Two studies in a meta-analysis of overweight or obese adult subjects, and one review of overweight and obese children, showed that diet was more relevant than exercise in improving lipid profiles, although much information suggests physical exercise does lead to improvement blood pressure and body composition.

Meta-analytical studies that carried out endurance training with different program structures, most studies had a duration of 10-12 weeks. A weekly frequency of three times and a duration of 30-60 minutes. Total duration of between 1080 and 6480 minutes with an intensity of 55-75\% MHR up to $70-90 \%$ MHR. Two studies reported 
a decrease in TG after an endurance exercise program. Exercise was said to be effective for lowering triglycerides when the program was carried out for more than 3000 minutes. These results indicate that in obese children, exercise volume is not decisive for improvement of lipid profile, this has also been reported in another crosssectional study which found that daily physical activity and blood lipid concentration generally showed little association. Analysis of a study group stated that the frequency of exercise for TG needs four or more per week for improvement with a program duration of more than 12 weeks (Escalante et al, 2012).

In this study using a program duration of 1440 minutes in 8 weeks, the compliance of subjects in this study was $80 \%$, only $25 \%$ of research subjects with abnormal TG, and the absence of calorie restriction were thought to be factors that contributed to the results of the study which were not significant to improve TG.

In this study, the endurance intervention with zumba fitness 3 times a week for 8 weeks had a sufficient effect on TG (effect size 0.51). This may be associated with a significant decrease in BMI, abdominal circumference and subcutaneous fat and a very large effect size. Barneveld et al (1989) stated: abdominal circumference, subscapular skinfold and body mass index all had similar positive relationships with total cholesterol, triglycerides, and diastolic blood pressure. The relationship between obesity and triglycerides is indicated by excess fat, especially TG which is an energy reserve and the largest amount is in adipose tissue (Shier et al, 2006). Anastasia (2011) stated that there was a significant correlation with weak correlation strength between BMI, triceps skinfold and triglycerides.

\section{Analysis of LDL (Low Density Lipoprotein) Pre and Post Endurance Exercise}

This study explains that there is a significant difference for LDL. There was a $4.9 \%$ decrease in LDL with a large effect size. $50 \%$ of subjects included in the category of dyslipidemia, from $50 \%$ of subjects with dyslipidemia, $66 \%$ of subjects with abnormal LDL, no calorie restriction.

Analysis of a study group stated that the frequency of exercise three times a week or less, was effective in improving HDL-C and LDL-C lipid profiles, whereas for TG it took four or more per week for improvement. Improvements in HDL-C were achieved with programs of less than 12 weeks duration, in TG with programs of more than 12 weeks duration, and in LDL-C with different duration programs ( $\leq 12$ weeks and $>12$ weeks) (Escalante et al, 2012).

Ben Ounis et al (2008) compared the effects of endurance exercise, dietary restriction intervention and a combination of endurance exercise and dietary restriction. The study was conducted on obese male adolescents aged 12-14 years. Endurance exercise by running, jumping and playing ball which is done 4 times a week for 2 months. The dietary restriction intervention demonstrated fat loss, and improved total and LDL-C cholesterol, whereas the exercise-only intervention increased lipid oxidation during exercise, improved plasma triglyceride insulin resistance, and increased HDL-C. Diet combined with exercise resulted in further improvements in body composition, insulin resistance and serum lipid profile, and also offered further benefits for HDL-C, HDL-C/TG ratios and LIPOXmax measures.

Leon and Sanchez (2001) conducted a meta-analysis of 51 interventions involving 12 or more weeks of aerobic exercise. It was reported that, on average, HDL cholesterol increased $4.6 \%$, triglycerides decreased by $3.7 \%$ and LDL decreased by 5\%. Total cholesterol remained unchanged, although the HDL, LDL cholesterol ratio increased rapidly, suggesting that the increases in intensity and structure typically associated with aerobic exercise have a more consistent impact on triglycerides and LDL than moderate physical activity.

Friedland et al (2002) found a significant positive relationship between adiposity and BMI, serum cholesterol and LDL. Previous cross-sectional studies have shown a positive correlation between body mass index and serum cholesterol and LDL cholesterol in children, with correlation coefficient values ranging from 0.04-0.26. In this study, BMI, abdominal circumference and subcutaneous fat decreased significantly with a very large effect size after the intervention and was followed by a significant decrease in LDL.

\section{Analysis of HDL (High Density Lipoprotein) Pre and Post Endurance Exercise}

This study explains that there is no significant difference for HDL. There was an increase in HDL of $12.49 \%$ but based on the effect size the effect was small. Findings from a recent meta-analysis of Escalante et al (2012), discussing aerobic exercise and lipid profiles in children and adolescents conducted in the United States, stated that short-term endurance exercise did not improve HDL-C, LDL-C, or TC lipid profiles, but reduced TG (Escalante et al, 2012).

Analysis of a study group stated that the frequency of exercise three times a week or less was effective in improving HDL-C and LDL-C lipid profiles, whereas for TG it took four or more per week for improvement. Improvements in HDL-C were achieved with programs of less than 12 weeks duration, in TG with programs of 
more than 12 weeks duration, and in LDL-C with different duration programs ( $\leq 12$ weeks and $>12$ weeks) (Escalante et al, 2012). This is contrary to the results of this study, where the intervention of endurance training with zumba fitness 3 times a week for 8 weeks, without calorie restriction did not increase HDL significantly.

Couillard et al (2001), compared the responses of various lipoprotein-lipid variables to a 20-week endurance training program with a 30-minute cycle ergometer, 4 times a week in men stratified by baseline TG and HDL cholesterol concentrations: (1) low TG and high HDL (normolipidemic), (2) low TG and low HDL (isolated low HDL), (3) high TG and high HDL (isolated high TG), and (4) high TG and low HDL (high TG/low HDL). Endurance exercise-induced increase in HDL levels $0.4 \%$ (not significant) in isolated low HDL men. In contrast, men with high TG/low HDL showed a significant increase in HDL cholesterol levels $(4.9 \%, \mathrm{P}<0.005)$. Whereas both subgroups of men with high TG levels showed a decrease in plasma TG levels $(\mathrm{P}<0.005)$, only those with high TG/low HDL showed a significant decrease in apolipoprotein B levels at the end of the study $(-6.0 \%$, $\mathrm{P}<0.005)$. The results of this study suggest that regular endurance training may be particularly helpful in men with low HDL, high TG, and abdominal obesity. In this study only $25 \%$ of study subjects had high TG, and only $8.3 \%$ subjects with low HDL.

\section{Analysis of Total Cholesterol Pre and Post Endurance Exercise}

In this study, it was explained that there was no significant difference for total cholesterol. There was a $3.6 \%$ decrease in total cholesterol with a small effect size. There is no calorie restriction and there is no control over the type of diet consumed, this is thought to be a contributing factor to the insignificant difference. Total cholesterol is the same as TG which in addition to coming from reserves in the liver, the two fat profiles are also influenced by dietary factors. Gadha (2009), cholesterol as much as $75 \%$ is formed in the liver, while $25 \%$ is obtained from food intake. Gadha stated that the increase in cholesterol levels above the normal value was caused by excessive intake of foods derived from animal fats, eggs and foods that are currently referred to as junk food. Food intake will affect the inflammatory process (Figueiredo et al, 2017).

The findings from a recent meta-analysis of Escalante et al (2012), discussing aerobic exercise and lipid profiles in children and adolescents conducted in the United States stated that short-term endurance exercise did not improve HDL-C, LDL-C, or TC lipid profiles, but reduces TG. Leon and Sanchez (2001) conducted a metaanalysis of 51 interventions involving 12 or more weeks of aerobic exercise. It was reported that, on average, HDL cholesterol increased $4.6 \%$, triglycerides decreased by $3.7 \%$ and LDL decreased by $5 \%$. Total cholesterol remained unchanged, although the HDL: LDL cholesterol ratio increased rapidly, suggesting that the increases in intensity and structure typically associated with aerobic exercise have a more consistent impact on triglycerides and LDL than moderate physical activity.

\section{CONCLUSION}

Based on the results of the analysis above, it can be concluded that endurance exercise with Zumba fitness without calorie restriction, 3 times a week for 8 weeks in obese male adolescents does not reduce triglycerides and total cholesterol, and cannot increase HDL. Endurance exercise with Zumba fitness without calorie restriction, 3 times a week for 8 weeks in obese male adolescents can reduce LDL. In this study, there are limitations, namely only taking male adolescent subjects, so the results cannot be generalized. Researchers suggest in future research to determine the effect of endurance training on a more diverse population (female and male subjects) and exercise protocols (variation in volume and duration of exercise adjusted to target lipid profile) to prove the effect of endurance training with Zumba fitness, so that it can be recommended the best exercise for lipid profile changes in obese adolescents.

\section{REFERENCES}

Adam JMF, Sudoyo AW, Setiyohadi B, Alwi I, Simadibrata M, Setiati S. 2006, Dislepidemia, Buku Ajar Ilmu Penyakit Dalam Ed.4. Jakarta: Interna Pusblishing

Alon Eliakim and Dan Nemet, 2010, Exercise and Childhood Obesity, Pediatric Obesity Etiology, Pathogenesis, and Treatment, Division of Pediatric Endocrinology and Diabetes Duke University.

Anastasia, 2011, Korelasi BMI dan Triceps skinfold thickness terhadap trigliserida, Fakultas Farmasi Universitas Sanata Dharma Yogyakarta.

Aucouturier, J and Thivel, D. 2015. Physical Activity Intervention In Overweight/Obese Children And Adolescents: Endurance And/Or Resistance Training?. European Childhoold Obesity Group. Diakses dari ebook.ecog-obesity.eu 
Barneveld, J C Seidell, N Traag, J G Hautvast, 1989, Fat distribution and gamma-glutamyl transferase in relation to serum lipids and blood pressure in 38-year old Dutch males, Department of Human Nutrition, Agricultural University, Wageningen, The Netherlands.

Ben Ounis, Elloumi, Ben Chiekh, A. Zbidi, M. Amric, G. Lacb, Z. Tabka, 2008, Effects of two-month physicalendurance and diet-restriction programmes on lipid profiles and insulin resistance in obese adolescent boys, Faculty of Medicine Ibn El Jazzar, 4002 Sousse, Tunisia

Blanca Romero Moraleda, Esther Morencos, Ana Belén Peinado, Laura Bermejo, Carmen Gómez Candela, Pedro José Benito, 2013, Can the exercise mode determine lipid profile improvements in obese patients. University of Madrid and University Hospital La Paz. Madrid. Spain.

Brian W. McCrindle, 2010, Pathogenesis and Management of Dyslipidemia in Obese Children, Pediatric Obesity Etiology, Pathogenesis, and Treatment, Division of Pediatric Endocrinology and Diabetes Duke University.

Castellani J, Fulco C, Kenefick R, Muza S, Pate R.2014. Chapter 8: Exercise Prescription for Healthy with Specail Considerations and Enviromental Consideration. ACSM's Guideline for Exercise Testing and Prescription 9th Edition.

Connie W. Bales, Victoria H. Hawk, Esther O. Granville, Sarah B. Rose, Tamlyn Shields, Lori Bateman1, Leslie Willis1, Lucy Piner1, Cris A. Slentz1, Joseph A. Houmard, Dianne Gallup1, Greg P. Samsa1, and William E. Kraus, 2012, Aerobic and Resistance Training Effects on Energy Intake: The STRRIDE AT/RT Study: Exercise Training Effects on Energy Intake, Associate director for Education/Evaluation, Geriatric Research, Education and Clinical Center, Fulton street Durham, NC

Couillard C, Jean-Pierre Després, Benoît Lamarche, Jean Bergeron, Jacques Gagnon, Arthur S. Leon, D. C. Rao, James S. Skinner, Jack H. Wilmore, and Claude Bouchard, 2001, Effects of Endurance Exercise Training on Plasma HDL Cholesterol Levels Depend on Levels of Triglycerides Evidence From Men of the Health, Risk Factors, Exercise Training and Genetics (HERITAGE) Family Study, America Hearth Association.

Damayanti Rusli Sjarif; Lanny Christine Gultom; Aryono Hendarto; Endang Dewi Lestari; I Gusti Lanang Sidiartha; Maria Mexitalia, 2014, Diagnosis, Tata Laksana dan Pencegahan Obesitas pada Anak dan Remaja, Rekomendasi Ikatan Dokter Anak Indonesia

Departemen kesehatan, 2013, Riset kesehatandasar (RISKESDA).

Elissa Jelalian and E. Whitney Evans, 2016, Behavioral intervention in the treatment of obesity in children and adolescents: implications for Mexico, Published by Oxford University Press on behalf of the International Life Sciences Institute

Escalante, Saavedra, Antonio García-Hermoso, Ana M. Domínguez, 2012, Improvement of the lipid profile with exercise in obese children: A systematic review, preventive medicine.

Friedland, Dan Nemet, Natalia Gorodnitsky, Baruch Wolach1 and Alon Eliakim, 2002, Obesity and Lipid Profiles in Children and Adolescents, Journal of Pediatric Endocrinology \& Metabolism.

FKM - UI. 2007. Aktivitas Fisik. Diunduh dari: http://lontar.ui.ac.id/. 3 November 2019

Figueiredo, Aline Carla Inada, Gabriela Marcelino, Carla Maiara Lopes Cardozo, Karine de Cássia Freitas, Rita de Cássia Avellaneda Guimarães, Alinne Pereira de Castro, Valter Aragão do Nascimento and Priscila Aiko Hiane, 2017, Fatty Acids Consumption: The Role Metabolic Aspects Involved in Obesity and Its Associated Disorders, Nutrients.

Gandha N. 2009. Hubungan Perilaku Dengan Prevalensi Dislipidemia Pada Masyarakat Kota Ternate Tahun 2008. Fakultas Kedokteran UI.

Gunawan A, Hedison Polii, Damajanty, H. C. Pengemanan. 2015. Pengaruh Senam Zumba Terhadap Kebugaran Kardiorespirasi Pada Mahasiswa Fakultas Kedokteran Universitas Sam Ratulangi Angkatan 2014. Jurnal e-Biomedik (eBm), Volume 3, Nomor 1. Manado: Universitas Sam Ratulangi

Gurevich-Panigrahi, 2009; Obesity: Pathophysiology and Clinical Management National Collaborative on Childhood Obesity Research.

Helen N Sweeting, 2008, Gendered dimensions of obesity in childhood and adolescence, MRC Social and Public Health Sciences Unit, 4, Lilybank Gardens, Glasgow, G12 8RZ, UK

Hoffman D.J and Gallagher D., 2001.Obesity and Weight Control. Downey \& Darling's Physiological Basis of Rehabilitation Medicine. 3rd Ed. USA, pp. 485-505

Jeffrey F Horowitz and Samuel Klein, 2000, Lipid metabolism during endurance exercise, American Society for Clinical Nutrition.

Kaniawati Marita, Sukmawati Ika, Manik Theresia, 2019, Hubungan antara Obesitas dengan Profil Kolesterol LDL, Apolipoprotein B dan small dense LDL pada remaja. Fakultas Farmasi Universitas Bhakti Kencana, Jurnal Farmasi Galenika Vol. 6 No.3

Kenneth R Feingold, and Carl Grunfeld, 2018, Obesity and Dyslipidemia, National center of Biotechnology information, U S, National Library of medicine, https://www.ncbi.nlm.nih.gov /books/NBK305895 /March 30th 2020. 
Kravitz and Heyward, Getting a Grip on Body Composition, Lange Cambridge Scientific Industries.

Laela nur, 2016, Hubungan senam Zumba dengan indeks massa tubuh.Universitas Muhammadiyah Surakarta.

Leon A, Sanchez O, 2001. Response of blood lipids to exercise training alone or combined with dietary intervention. Med Sci Sports Exerc.

Mary S. Ahn, Boris Birmaher, Lisa Cullins, Timothy Dugan, Gregory K. Fritz, Mary Margaret Gleason, Pamela E. Hoffman, Melvin D. Oatis, Scott M. Palyo, Marian A. Swope, John T. Walkup, 2016, Obesity In Children And Teens, American Academy of Child and Adolescent Psychiatry.

Madarina Julia, 2014, Obesitas pada Anak, IDAI Indonesian Pediatrics Society, Bagian Ilmu Kesehatan Anak, Fakultas Kedokteran UGM/ RS Sardjito Yogyakarta, http://www.idai.or.id/artikel/seputar-kesehatananak/obesitas-pada-anak/ 25 December 2018.

Manjula Suri, Rekha Sharma Namita Saini, 2018, Physiological responses of Zumba: an Overview understanding the popular fitness trend, Department of Physiology and Promotive Health, University of Delhi, Institute of Home Economics, India

Masuko Ushio-Fukai, 2013. Anti-Atheroscrerotic Drugs. Dept of Pharmacology University of Illinois at Chicago

M. Cauderay, F. Cachat, 2015, Analysis of exercise training for treating obesity in children and adolescents: a review of recent, Department of Pediatrics, Division of Pediatric Nephrology, Bern, Switzerland.

McManus dan Mellecker, 2012, Physical activity and obese children, Institute of Human Performance, University of Hong Kong, China

McWhorter J.W, Wallman,H.W, and Alpert, 2003. The Obese Child: Motivation as Tool for Exercise. Journal of Pediatric Health Care. Las Vegas.

Mehdi Mogharnasi, Rasul Eslami, Behzad Behnam, 2014, Effects of Endurance and Circuit Resistance Trainings on Lipid Profile, Heart Rate, and Hematological Parameters in Obese Male Students, Kerman Science and Research branch, Islamic Azad University, Kerman, Iran.

Michael Freemark, 2010, Pediatric Obesity Etiology, Pathogenesis, and Treatment, Division of Pediatric Endocrinology and Diabetes Duke University.

Muryati Patima, A. Suswan, 2014, Latihan Aerobik Terhadap Perubahan Indeks Massa Tubuh (IMT) pada Individu Overweight dan Obesitas, Stikes Panrita Husada Bulukumba.

Neslihan Koyuncuoğlu Güngör, 2014, Overweight and Obesity in Children and Adolescents, Louisiana State University Health Sciences Center-Shreveport, Department of Pediatric Endocrinology, Shreveport, LA, USA

Nicholas P. Greene, Steven E. Martin and Stephen F. Crouse, 2012, acute Exercise and training alter Blood Lipid and Lipoprotein Profiles Differently in Overweight and Obese Men and Women, Texas A\&M University, College Station, Texas, USA, www.obesityjournal.org

PMK No.43, 2013, Cara Penyelenggaraan Laboratorium Klinik yang baik. Menteri Kesehatan Republik Indonesia.

Putu Dyana, 2011, Korelasi Body Mass Index dengan tricep skinfold thickness terhadap rasio kadar LDL/ HDL

Redinger Richard N, 2007, The Pathophysiology of Obesity and Its Clinical Manifestations, Department of Medicine at the University of Louisville.

Roya Kelishadi, Mahin Hashemipour, Ahmad Sheikh-Heidar, Shohreh Ghatreh-Samani, 2012, Changes in serum lipid profile of obese or overweight children and adolescents following a lifestyle modification course, ARYA Atherosclerosis Journal 2012, 8(3): 143-148.

Shenghui Wu ,-Shin Park ,and Joseph B. McCormick, 2017, Effects of Exercise Training on Fat Loss and Lean Mass Gain in Mexican-American and Korean Premenopausal Women, International Journal of Endocrynology.

Shah SZA, Devrajani BR, Devrajani T, Bibi I. 2008, Frequency of Dyslipidemia in Obese versus Non-obese in relation to Body Mass Index (BMI), Waist Hip Ratio (WHR) and Waist Circumference (WC). Pakistan Journal of Science.

Shier D, Butler J, and Lewis R, 2006, Holes's essential of human anatomy and physiology, Ninth ed, Mc Graw Hill Higher Education, New York.

Sjarif D, Nasar S, Devaera Y, dan Tanjung C. 2011. Asuhan Nutrisi Pediatrik. Ikatan Dokter Anak Indonesia.

Sjarif D, Gultom L, Hendarto A, Lestari E, Sidiartha I, danMexitalia M. 2014. Diagnosis, Tatalaksana dan Pencegahan Obesitas pada Anak dan Remaja. Ikatan Dokter Anak Indonesia.

Sukma A.T. 2015. Efek Zumba Terhadap Penurunan Tebal Lemak Tubuh Bawah Kulit dan Berat Badan Member DF Fitness dan Aerobic. Jurnal e-Biomedik (eBm). Yogyakarta: Universitas Negeri Yogyakarta

Suliga Edyta, 2009, Visceral adipose tissue in children and adolescents: a review, Cambridge University Press.

SoJung Lee, Fida Bacha, Tamara Hannon, Jennifer L. Kuk, Chris Boeschand Silva Arslanian, 2012, Effects of Aerobic Versus Resistance Exercise Without Caloric Restriction on Abdominal Fat, Intrahepatic Lipid, and Insulin Sensitivity in Obese Adolescent Boys A Randomized, Controlled Trial, diabetes.diabetesjournals.org. 
Umamaheswari Kannan, Kavita Vasudevan, Kavita Balasubramaniam, Dhanalakshmi Yerrabelli, Karthik Shanmugavel, Nitin Ashok John, 2014, Effect of Exercise Intensity on Lipid Profile in Sedentary Obese Adults, Department of Physiology, ESIC Medical College \& PGIMSR, K.K. Nagar, Chennai, India.

Utomo GT, dkk, 2012 Latihan Senam AerobikUntuk Menurunkan Berat Badan,Lemak, Dan Kolesterol, Jurusan Ilmu Keolahragaan, Fakultas Ilmu Keolahragaan, Universitas Negeri Semarang, Indonesia.

WHO, 2014, Obesity, https://www.who.int/topics/obesity/en/ 22 April2019

WHO, 2016, Childhood overweight and obesity, https: //www.who.int /dietphysicalactivity /childhood/en/April21th 2019.

William S. Garver•Sara B. Newman•Diana M. Gonzales-Pacheco•Joseph J. Castillo•David Jelinek•Randall A. Heidenreich Robert A. Orlando, 2013, the genetics of childhood obesity and interaction with dietarymacronutrients, Springer-Verlag Berlin Heidelber. 